\title{
VARIOUS TYPES OF THE ROTORCRAFT DESIGN IN THE CONTEXT OF AEROSPACE REGULATIONS
}

\author{
Krzysztof Szafran, Marcin Michalczyk \\ Institute of Aviation, \\ al. Krakowska 110/114, 02-256 Warsaw, Poland \\ krzysztof.szafran@ilot.edu.pl,marcin.michalczyk@ilot.edu.pl
}

\begin{abstract}
In the next article on synthesis of regulations, the authors presented the general legal requirements for rotorcraft, which is limited to US regulations, because the vast majority of world regulations are based on them. The Institute of Aviation in Warsaw has developed requirements concerning the construction and operation of rotorcraft in Poland. These requirements constitute an important contribution to the regulations of the Civil Aviation Authority which are in force in the air space of the Republic of Poland. This paper presents the legal situation of rotorcraft and compares the requirements for helicopters and gyroplane. The conclusions highlighted the differences that arise from regulations between helicopters and rotorcraft. The authors have suggested the necessity to separate provisions for the group of windmills, which is implemented in the regulations of the Civil Aviation Authority. The presented work is the second of a planned series of publications in which authors intend to bring some of the issues to the reader about the design aspects of aircraft in selected global aviation regulations.
\end{abstract}

Keywords: aviation regulations, certification, flight safety, helicopters, rotorcraft, gyroplane.

Basic indications:

CAA - Civil Aviation Authority

FAR - Federal Aviation Regulations

ASTM - American Society of Testing and Materials

$\mathrm{POH}$ - Pilot Operating Handbook

TDP - Take-Off Decision Point,

LDP - Landing Decision Point 


\section{INTRODUCTION}

Briefly, two years after the successful flight of the Wright Brothers plane, the first rotor rises in the air. The story is funny because it was the construction of the French bicycle maker Paul Cornu. The performance that the machine could boast was a short hoist at a height of just over a meter above the launch surface. The first helicopter (in today's sense of the word) constructed the German engineer Heinrich Focke in 1936. Its construction was based on a hull borrowed from an aircraft of its own design with two rotors mounted on truss jibs.

Focke-Wulf Fw 61 could not have been built without the previous achievements of other engineers. The work of Russian engineer Boris Jurjev and the Spanish engineer Huana de la Cierva has enabled the construction of impellers with articulated blade locks and a controlled stroke, both general and periodic [1]. Cierva built a rotor called autogiro, which was different from the other that the rotor was not driven by the engine and the air flowing. As early as 1928, the C.4 model made successful, stable flights. The machine was not able to hang still in the air, which translated into a lack of interest in this type of solution by other builders.

Still in the air, a helicopter designed by Igor Sikorski was built in 1939. The helicopter had one rotor and tail propeller. Such a system is today called classic and is present in the vast majority of manufactured machines. After Sikorski's construction there was a sudden increase in interest in helicopters and today they are used both in civil and military aviation.

Windmills, although they have been known since the 1930s, have only recently returned to the aviation industry's favor and are only light-duty recreational aircraft. It has been possible to certify them not only as experimental units, but also as ultralight and light sport aircrafts for several years.

In Europe, the law is almost equal to light aircraft. Organizations such as the British CAA have already been able to fly gyroplane areas under the same conditions as for light aircraft $[2,6]$. The gyroplane project recently completed at the Institute of Aviation involves the design, construction and testing of a new type of transport. It was the first time in Poland under the supervision of the ULC a complete set of tests and calculations allowing the I-28 gyroplane in accordance with ASTM 2352-09 [6,7].

\section{TYPES OF CERTIFICATION}

Today's aviation law allows you to certify rotorcraft in two categories [3,6]. Both categories allow for different configurations, as shown in Table 1. Lightweight sports gyroplane are constructed according to ASTM F2352 - Standard technical terms for the design and performance of lightweight sports gyroplanes. This standard cannot be considered as a type of certification similar to the US FAR or the British CAA.

Table 1. Robustness certification categories [3]

\begin{tabular}{|l|c|c|c|c|c|}
\hline TYPE & Category & Type of rotorcraft & Mass & Passenger & Engine \\
\hline \multirow{3}{*}{ FAR 27 } & - & Rotorcraft & $\begin{array}{c}3175 \mathrm{~kg} \\
(7,000 \mathrm{lb} .)\end{array}$ & 9 & 1 \\
\cline { 2 - 6 } & $\mathrm{A}$ & Rotorcraft & $\begin{array}{c}3175 \mathrm{~kg} \\
(7,000 \mathrm{lb} .)\end{array}$ & 9 & multi \\
\hline
\end{tabular}




\begin{tabular}{|l|c|c|c|c|c|}
\hline TYPE & Category & Type of rotorcraft & Mass & Passenger & Engine \\
\hline \multirow{2}{*}{ FAR 29 } & A & Rotorcraft & - & 10 and more & multi \\
\cline { 2 - 6 } & B & Rotorcraft & $\begin{array}{c}9072 \mathrm{~kg} \\
(20,000 \mathrm{lb} .)\end{array}$ & 9 & multi \\
\hline ASTM F2352 & - & Gyroplanes & $\begin{array}{c}725 \mathrm{~kg} \\
(1,600 \mathrm{lb} .)\end{array}$ & 2 & 1 \\
\hline
\end{tabular}

Type acc. The FAR 27 is designed for small propellers with a maximum take-off mass of up to $3175 \mathrm{~kg}$, with a maximum of 9 seats for passengers. These drills can be certified according to category A, which allows constructors to install more than one drive unit. In this case, however, it is necessary to fulfill all the requirements specified in the dedicated annex (FAR 27 Appendix C: Criteria for Category A). This annex is a list of several dozen requirements taken from the next category dedicated to rotorcraft - FAR 29.

Type acc. FAR 29 is designed for large rotors used in civilian transport. The FAR 29 requirements divide the rotorcraft into two categories: $\mathrm{A}$ and $\mathrm{B}$. The rotor with a maximum takeoff mass of more than $9072 \mathrm{~kg}(20,000 \mathrm{lb}$.) and with a seating capacity equal to or greater than 10 must be certified according to type A, $9072 \mathrm{~kg}$ and the machine is equipped with a maximum of 9 seats for passengers it is possible to certify such a type B, which is slightly less rigorous.

Lightweight gyroplane constructed on the basis of ASTM F2352 must not exceed a maximum take-off mass of $725 \mathrm{~kg}(1600 \mathrm{lb}$.) and take more than 2 passengers on board. Impellers must have a constant blade angle, which excludes the possibility of building a helicopter based on this standard. In addition, the engine must be equipped with a fixed pitch propeller or mounted on the ground. The requirements of ASTM F2352 clearly state that a construction can only be designed for sport and recreation and that commercial use is very limited, even if the number of seats on the deck is limited to two.

\section{CERTIFICATION REQUIREMENTS FOR FLIGHT MECHANICS}

The categories clearly state in which cases the flight mechanic data will be accepted. Unless specified otherwise, compliance testing shall be performed for the most unfavorable combination of start mass and center of gravity determined in the tests. The above permitted take off masses for rotor blades. FAR 27 and FAR 29 concern passenger flights. Both categories allow the operation of air operations with higher take off mass, but only for cargo flights. In this case, however, it is necessary to perform the test calculations and to confirm in the tests that the main rotor is able to withstand an overload of $2.5 \mathrm{~g}$. The permissible maximum front and rear center of gravity should also be determined. The strength of the fuselage structure must be proven throughout the manufacturer's documentation of the center of gravity. If the certification requirement does not say otherwise, it must be fulfilled throughout the center of gravity. For all required tests and tests, the use of detachable ballast is acceptable. Similar requirements (except for cargo flights) apply to ASTM F2352.

\subsection{Main rotor speed range}

The speed of the main rotor must be determined in such a way that, when the drive is switched on, a sufficient margin for rotor speed changes resulting from correctly maneuvers is provided. The speed of the rotor should be in line with the capabilities of the blades control mechanism. In the absence 
of propulsion, the rotor speed range must allow for maneuvering at autorotation for the entire range described in the documentation, the range of speed limits for the rotor.

For some helicopters (excluding helicopters), it should be demonstrated that the maximum speed of the main rotor from its approved minimum speed is not significantly lower at the maximum allowable engine speed and at the maximum blade attack angles and for fixed flight conditions. This is accomplished by adjusting the large rotor stop, proper rotor design, and pilot warning signaling of dangerous speed. In the absence of power, it is necessary for the manufacturer to demonstrate that, with the minimum allowable blade pitch angle, the most critical combination of takeoff mass and center of gravity position, it was possible to autorotate the rotor to the speed of emergency landing. It is also necessary to allow the pilot to prevent autorotation of the rotor over the maximum speed (overdrive of the main rotor).For helicopters, one more requirement is required for the speed of the rotor. For all single-engine helicopters and those with multiple engines that do not have systems that automatically boost the power of the actuators in case of failure of one of them, an alarm system with dangerously low rotor speeds is required. Such a system must alert the pilot in all flight conditions, both on the engine fly and on the fly in case the rotor speed may endanger flight safety. Such a system can be installed in the cockpit instrument form, but it can also be an aerodynamic alarm of rotor blades (sensible vibrations at low rotational speeds of the rotor).

ASTM F2352 requires that a safe rotor speed range is established and stored in the $\mathrm{POH}$ flight manual. The safe rotor speed range is one that allows you to safely execute any intended maneuver.

\section{PERFORMANCE}

Flight safety is directly affected by the performance of each type of aircraft. The first important safety criterion in terms of achieved flight parameters is the possibility of safe hovering in the air. For small helicopters acc. The FAR 27 must be proven to be capable of vertical takeoff and hovering of up to $1219 \mathrm{~m}(4,000 \mathrm{ft}$.) in piston engine or $762 \mathrm{~m}(2,500 \mathrm{ft}$.) in turbine engine operation. For helicopters other than helicopters, that is to say, gyroplane only, it is impossible to start at any height without a component of velocity vector parallel to the vector of wind speed. The regulations therefore require the predetermined rate of climb for the minimum velocity of the rotor. All requirements must be met for the maximum take-off weight.

As for the analogous requirements for type according to. FAR 29 makes it very difficult to say whether they are more stringent than those contained in the FAR 27 requirements. These requirements are very close to each other, but differ in the fact that there is no requirement for a vertical hoist at a particular height. The main difference, however, is that for both categories A and B it is necessary to prove a safe hinge at the height specified by the manufacturer, with all startup procedures (including such procedures as an emergency stop, etc.). Small rotorcraft require the power required to perform a safe start. Any tests must be carried out with maximum front center of gravity. The starter may not require the crew of above-average piloting skills and must allow him / her to stop at any time in such a way that a safe landing can occur. The required launch requirements must be achieved not only when taking off from the elevation equal to the altitude but also from the height to which the propeller can be raised or from the height of $2134 \mathrm{~m}(7,000 \mathrm{ft}$.), whichever is the lower. This makes it possible to make safe maneuvers for take-off from any achievable height rotor.

The FAR 29 requirements make it possible to take off only from smooth, hardened surfaces. The start-up requirements for category A rotor blades are much more stringent. They accurately describe what performance must be followed by rotor blades for all scenarios of dangerous situations during take-off. 
Since this category concerns large, mainly turbine-powered helicopters capable of taking over 10 passengers, the start-up procedure is very complicated and is thoroughly described in the certification requirements. The rules define the decision point at the start of the TDP, which specifies the time at which a safe, emergency break of the start procedure is allowed. A TDP can be described as no more than two parameters, such as flight speed and altitude. The rules are very stringent, to minimize the risk of injury or death during use of the rotor. In today's aviation the greatest risk is the human factor, which is hard to investigate, and even more difficult to describe the procedures that will eliminate this factor [4]. Despite the impossibility of eliminating the human factor, the regulations try to minimize this factor. Such attempts are seen in the records that say that when determining a TDP it is necessary to take into account the time that the crew needs to know in a dangerous situation and to make a decision. Beyond the TDP, the start-up procedure described in the rules still requires a startup path. This path ends at an altitude of $305 \mathrm{~m}$ above the starting surface. The path describes the main assumptions of each startup procedure in the event of an emergency such as a single engine failure or an unexpected drop. The path also describes a number of things that can or should be done at start-up, such as the clearly defined requirements for which instruments to perform the procedure or when the chassis can be retracted. In the case of taking off from a landing site on a high elevation, a number of additional requirements must be met. These requirements describe when the rotor may be below the take-off elevation, i.e. after the minimum takeoff speed and at a distance of $4.6 \mathrm{~m}$ from the edge of the landing area. Such requirements are quite intuitive and clearly prevent situations in which the rotor Right after the start, he would be in danger. Large Category A treadmills have one more start requirement, and its emergency break. In the event of an interruption of take-off, a number of important requirements for emergency procedures must be met. Startup interruptions are often the result of a failure signal on one of the motors. Operate the remaining engines only and only to their approved limits, so that they do not risk further failures.

Standard ASTM F2352 only requires the length of the segment required to start the gyroplane until it reaches a height of 15 meters. The horizontal length of the section must be determined for the start of the rotor and for the start of the rotor.

During the certification of helicopters acc. FAR 27, it is necessary to determine the maximum climbing speed and climbing angle for the permitted speed range and the achievable ceiling. For gyroplane the requirements are similar. The climb rate must be determined, but the climbing angle must meet a specific requirement, it must be at least 1:10 if the horizontal distance required to overcome the $15 \mathrm{~m}$ hurdles or 1: 6 is measured at sea level. In addition, the parameters described above for a situation where one motor fails. Type FAR 29 is almost identical in the case of climbing with all efficient engines. However, if one of the drives fails, the FAR 29 certification requirements are more stringent. They take into account the influence of the earth on the behavior of the rotor and, in the event of this phenomenon, the climb rate must be at least $46 \mathrm{~m}$ per minute, and without the impact of the earth, this speed must be $61 \mathrm{~m}$ per minute.

Standard ASTM F2352 only requires the determination of the climbing time from the gyroplane to the $300 \mathrm{~m}$ ceiling. This time must be less than 4 minutes and be stated in the flight manual.

As in the case of start-up performance, the rotor blades that need to meet during landing are much more rigorous for the category by. FAR 29. The FAR 27 requirements only describe that the landing rotor cannot perform a rapid acceleration, nor can it have a tendency to rock forward and backward, nose rattling, and cannot require a pilot's superior piloting skills. Spinners must be able to safely land in the event of a failure of all engines, i.e., on established autorotation. For gyroplanes by FAR 29, the procedure requires determination of a landing point for LDP analogue to TDP but only for category 
A rotor. The requirements of category A are that the approach speed and impeller at each point of the approach must be chosen in such a way that, The failure of one of the engines was possible to safely continue the landing or to climb. Category $B$ is described in a manner that requires specific parameters to be met: the horizontal section required for landing is defined from the point at which the rotor is at a height of $15 \mathrm{~m}$ until the total stop must be determined. As with Category A, it must be possible to safely land in the event of a loss of all motors. ASTM F2352 for landing is analogous to start. It is necessary to determine the length of the segment required to stop the gyroplane. This segment is measured from the moment the gyroplane reaches $15 \mathrm{~m}$ above the landing surface.

\section{CONTROLS AND MANUAL}

Each aircraft must also be capable of safely controlling and maneuvering in all phases of flight. The steering and maneuverability of the FAR rotor must be met without any obstruction to a minimum wind speed of $31 \mathrm{~km} / \mathrm{h}$. In the event of a failure of one or all of the engines, it is not permitted for the rotor to react to the rifle with a delay of more than 1 second. The pilot must be able to release the rotor blades at unbelievable speeds without over-piloting skills, and if this speed is exceeded by $10 \%$, the rotor must be able to control the tilt and tilt without any oscillation. Steering cannot show excessive play and resistance, the steering force must not show discontinuity over the whole range of motion, and zeroing on the steering controls must be possible for the entire range of permitted speeds. Longitudinal control must be designed in such a way that putting the rudder from one another results in increased speed and the rudder rises to one another.

The steering and maneuverability requirements are very similar. The numerical differences needed to demonstrate longitudinal stability in various flight phases are shown in Table 2.

Table 2. Longitudinal stability for different flight phases $[5,8]$

\begin{tabular}{|l|l|}
\hline Flight phases & Longitudinal stability requirements \\
\hline Climb & Longitudinal stability shall be demonstrated for the speed range from 0.85 VY to 1.2 VY. \\
\hline Crossing & Longitudinal stability shall be demonstrated for the speed range from 0.7 VNE to 1.1 VNE. \\
\hline Autorotation & $\begin{array}{l}\text { Proof of longitudinal stability under autorotation conditions in the speed range from half } \\
\text { the minimum fall speed to the VNE both with retracted and landing gear }\end{array}$ \\
\hline
\end{tabular}

The maneuverability and maneuverability described in ASTM F2352 is very similar to the FAR requirements. The number of requirements and ranges are comparable, but the difference lies in the numerical values of the specific requirements. In many cases, the ASTM F2352 does not require that predetermined numerical values of the measured stability and steering characteristics be met. As regards nature, the requirements are similar, while the amount of design and test work is comparable to that required for proof of compliance with the type of certification in the FAR.

\section{PROJECTING INFRASTRUCTURE}

Aviation law interferes in the design of rotorcraft much more than in the case of airplanes. Intrusion is very deep, however, very high convergence of types according to. FAR 27 and FAR 29-B allow you to postpone the selection of the right type beyond the initial stages of the certification process. 
From a performance point of view, choosing the right type of certification does not have to be the subject of a tender proposal. The trend is worldwide similar, logical and analogous to the regulations on airplanes: the goal is to increase security. The rotor is bigger, which is the same as how many passengers are able to take, the requirements are more stringent.

\section{CONCLUSIONS}

The differences in certification requirements of FAR 27 and FAR 29 may initially appear to be relatively small. Many requirements are repeated and are defined identically, others differ slightly. The differences between these types are, however, very large and are reflected in emergency records such as the power plant failure. Both types of theoretically allow certification of all types of helicopters: helicopters and gyroplane. While there are Cartesian Carter Copter commercial prototypes, there are no similar FAR 29 aircraft. FAR 29 theoretically allows the certification of helicopters other than helicopters, but very rigorous requirements from a practical point of view may not prevent, but significantly impede the design of a helicopter that is competitive to the helicopter. The lack of prototypes and historical experience seem to confirm this thesis. Lightweight gyroplanes are designed based on ASTM F2352, which is the basis for issuing airworthiness certificates and admission to flights or other similar documents. Such flights may only be operated under VFR conditions, but for recreational aviation this is an acceptable restriction.

The recent increase in interest in light aviation equipment and gyroplanes in the light aviation segment suggests that the regulations will be modernized, and that future FAR-specific grenades may only be released in the future $[6,7]$.

\section{BIBLIOGRAPHY}

[1] Katyshev G.I., 1986, "Sozdatel avtozhyra Juan de la Cierva (1895-1936)” (in Russian: “Создатель автожира Хуан де ла Сьерва (1895-1936)”), M, Science (Наука), p. 160.

[2] Van Wagenen, J., 2014, “CAA Removes Overflight Restrictions on Gyroplanes” Aviation Today, from http://www.aviationtoday.com/av/topstories/CAA-Removes-OverFlight-Restriction-on-Gyroplanes83426.html.

[3] FAR - Federal Aviation Regulations, a set of rules in the federal legislative system of the United States. Administrative law is divided into 50 topics, of which No. 14 refers to aviation and astronautics, also known as the FAA - Federal Aviation Administration.

[4] Szafran, K., 2014, "Flight Safety - Maximum entropy principle" Safety on land, sea and air in the 21 st century. Research Center for Fire Protection. Józefów, pp. 247-251.

[5] Szafran K., Michalczyk M., 2016, "Selected Topics in the Design of Lightweight Sports Airplanes in the Context of Global Aviation Law". Transactions of the Institute of Aviation, No. 2(243), p. $142-153$.

[6] Krzymień W., 2016, "Remarks on the requirements of the provisions of the construction of gyroplanes", ML-XVII, Mechanics in Aviation, Warsaw, PTMTS.

[7] Wiśniowski W., 2010, "Resonance Research of Flying Objects - Methods and Analysis of Results”, Institute of Aviation Studies, pp. 1-128.

[8] Federal Aviation Regulations FAR / CS 27.175, FAR / CS 29.175. 


\section{RÓŻNE TYPY WIROPŁATÓW W KONTEKŚCIE TWORZONYCH PRZEPISÓW LOTNICZYCH}

\section{Streszczenie}

W artykule autorzy przedstawili ogólne wymagania prawne stawiane wiropłatom, przy czym ograniczono się do przepisów obowiązujących w USA, ponieważ zdecydowana większość światowych przepisów opiera się właśnie na nich. W Instytucie Lotnictwa w Warszawie opracowano wymagania, które dotyczą budowy i eksploatacji wiatrakowców w Polsce. Wymagania te stanowią istotny wkład do opracowanych przez Urząd Lotnictwa Cywilnego przepisów obowiązujących w przestrzeni powietrznej RP. W niniejszej pracy zaprezentowano sytuację prawną wiatrakowców oraz porównano wymagania stawiane śmigłowcom oraz wiatrakowcom. We wnioskach uwypuklono różnice, jakie wynikają z przepisów pomiędzy śmigłowcami i wiatrakowcami. Autorzy zasugerowali konieczność wydzielenia przepisów dotyczących grupy wiatrakowców, co jest realizowane w przepisach Urzędu Lotnictwa Cywilnego. Zaprezentowana praca jest drugą z zaplanowanego cyklu publikacji, w której autorzy zamierzają przybliżyć czytelnikom pewne zagadnienia dotyczące aspektów projektowania statków powietrznych w wybranych światowych przepisach lotniczych.

Słowa kluczowe: przepisy lotnicze, certyfikacja, bezpieczeństwo lotów, wiropłat, śmigłowiec, wiatrakowiec. 